\title{
REALITY OF HUBRIS SYNDROME THROUGH HERMAN MELVILLE'S NOVEL MOBY DICK
}

\author{
Hidayati $^{1}$, Arifuddin ${ }^{2}$, Aflina ${ }^{3}$, Ratna Sari Dewi ${ }^{4}$ \\ 1,2,3 Universitas Harapan, Medan, Indonesia \\ ${ }^{4}$ Universitas Muslim Nusantara, Medan, Indonesia \\ e-mail: yatihida853@gmail.com
}

Received: 2021-04-21

Accepted: 2021-05-22

\begin{abstract}
Exposing hubris syndrome, a behavior pattern that is not in accordance with the norms of standard behavior and becomes part of a mental disorder is the objective of the study. This syndrome usually occurs in someone with power in hand, tending to be tyrannical and feeling to be always right. In the study of literature Hubris syndrome refers to the tragic flaw that brings a person, usually an important figure, to a self-destruction. Hubris syndrome can occur to anyone. The method used is descriptive qualitative tied to things experienced by the community termed a social phenomenon. The results show that the central figure in this novel, a captain of a whale-hunting vessel, experiences hubris syndrome with three prominent patterns of behavior: narcissistic propensity, excessive confidence and loneliness. In the first pattern, the person concerned feels like a superhuman deserving to be admired and attended to. The second, excessive selfconfidence cannot be accepted by rational thinking. The third is the consequence of the first two patterns of living a life of solitude because of losing contact with the surroundings. The storyline ends tragically; the entire crew is killed by the whale and only one left and becomes a narrator. Hubris syndrome in the novel is a reality meaning that anyone who has a certain position tends to have Hubris syndrome and this is in line with the findings in the field with a percentage reaching 92.
\end{abstract}

Keywords: Hubris syndrome, Narcissistic Propensity, Confidence, Loneliness.

\section{Introduction}

The novel was originally entitled The Whale and later changed to Moby Dick and was published in 1851 by Herman Melvile, an American novelist. This novel became famous in the 1900s and today the novel is not only regarded as one of the greatest classic American novels, but also one of the best novels written in English. The novel is also a reflection of the life of Herman Melville working on a whale-hunting vessel. The description of whale hunting, which is full of risks, is written based on Herman Melville's personal experience while working as a whale hunter. At that time the captured whales were sold to whale traders to extract the oil; surely with a tantalizing price. Therefore, this novel is also one of the most famous marine adventure novels in the world of English literature. 
Moby Dick is the magnum opus of Herman Melville, his master piece centered on a crew from the Pequod vessel named Ishmael who is also the novel's narrator. The vessel is led by Captain Ahab who has lost one of his legs, bitten by a whale on a previous expedition. This is the beginning of a series of events that build the novel's storyline. Captain Ahab then names the whale Moby Dick. The loss of one of his legs causes Captain Ahab to be in wrath and he vows to look for the fish all over the world; he harbors extraordinary feelings of revenge.

As a narrator, Ishmael, bridges the reader with the writer. Ishmael narrates his experiences and adventures in melancholic, depressive and impressive mood. Ishmael has visited various places such as Bedford, Nankantuket and in Nakantuket, he signs a work contract with the Pequod ship company to work on whaling voyages and on this ship, he meets a captain with an unusual personality, Captain Ahab. Captain Ahab is a veteran sailor who has a lot of experiences in shipping. Ahab is stubborn and intolerant and he always says that Moby Dick is responsible for the loss of his leg and with irrational thinking, gives orders to the entire crew that their aim is only to find Moby Dick.

He can do this because he has got absolute rights to the Pequod vessel from the ship company. He does not even think about the problems of the crew because he no longer limits the risk of shipping from the destination. For him, Moby Dick is the purpose of life and he has to kill the whale. He no longer cares about the problems around him; even he no longer thinks of his personal problems. He has forgotten his family and he feels that he now only lives alone with one purpose, namely to avenge himself on the whale. This is irrational because Ahab's revenge is not directed at a human but on a fish. Almost no one, a human, who has so much revenge on animals. An animal does not have feelings and goals when attacking a human as the actions of an animal are based on the instinct for defensive position. From here it is illustrated that Ahab's mental state is unstable, but could not be said to be insane because he could still carry out his position as a reliable ship captain.

There are three figures forming the basis of the journey of the storyline in this novel, namely: Ishmael as a narrator giving a complete description of the storyline to the reader, and basically Ishmael is a representative of Herman Melville; Captain Ahab, the protagonist the center of the storyline and a man with a heart always burning and Moby Dick, a whale hunted by Captain Ahab and the entire crew of Pequod. Moby Dick, although only a whale, is the basis of inspiration and conflict in this novel.

The novel begins with a famous statement: Call me Ishmael.

If you must give me a name, an identity, then call me Ishmael, for it is not important, nor does it matter who I am. I am not the focus of what I narrate. What I narrate is bigger, and more important than me". (Melville, 1851: Chapter I)

Ishmael becomes an icon of solitude and struggle because Ishmael does not introduce his name; he does not say his name is Ishamel, he simply says call me Ishmael and he just feels he has responsibility for the chronology of the entire journey of the ship. From the beginning working on the ship, he always seeks for information about Captain Ahab. Ishmael is the only sailor on the ship surviving from the counter-attack of the whale, Moby Dick.

In the midst of misery, insanity and the tense conditions emerging throughout the storyline, Ishamel and his friends realize that Captain Ahab is experiencing severe 
depression leading to madness. However they could not do much; as they have signed a work contract with a ship company and as crew, they have to obey the captain.

As soon as the Pequod ship starts sailing, the crew are told that their trip is not the same as that of other whale-hunting vessel because they have a special mission, only to find a whale named Moby Dick whose whereabouts are unknown. They have to find the whale all over the world.

And I'll chase him round Good Hope, and round the Horn, and round the Norway Maelstrom, and round perdition's flames before I give him up. And this is what ye have shipped for, men! To chase that white whale on both sides of land, and over all sides of earth, till he spouts black blood and rolls fin out. What say ye, men, will ye splice hands on it, now? I think you do look brave'" (Melville 36).

This is a picture of their journey immediately conveyed by Captain Ahab that he along with the entire crew has only one mission, to kill Moby Dick. The crew initially disagree, but Captain Ahab's orders are indisputable, as he states he is the god on the ship and they must obey his orders.

"There is one God that is Lord over the earth, and one Captain that is lord over the Pequod. - On deck!" (Melville, 1851: 109).

This shows that Captain Ahab is much obsessed with his glory and at the same time shows that he is experiencing a mental disorder. Ahab is the main character in the novel; a figure who has a controversial personality and is a symbolic character. Ahab's personality is reflected in the feud symbol of darkness versus natural forces; but behind all this, Ahab has a strong mentality, with very strong ambitions. With high charisma, he manages to make himself an undisputed dictator.

The research deals with the reality of hubris syndrome in the community through Moby Dick novel. Novel as one of the literary works serves to bridge the community with the author or in other words literary work is a medium for disclosing social problems. As a reflection of human life, literature touches all the aspects of human life, tending to create universal appeal. (Manugeren and Hidayati, 2018) Therefore hubris syndrome exists in any society or in short Hubris syndrome may be experienced by any person.

\section{Literature Review}

The main point of the discussion in this study is the syndrome of Hubris experienced by the central figure in the novel, Captain Ahab. In general, Hubris is a person's behavior leading to excessive self-confidence, high ambition and uncontrolled or arrogance standing outside the limits of acceptance of prevalence. Therefore, the word Hubris in literature is used to give a description of the tragic flaw of a hero resulting in a fall. (Diamandis and Nick, 2018)

In psychology, Hubris is a form of mental disorder; but based on pathological personality changes the process of occurrence is different. Mental disorder can occur or begin in childhood, while Hubris occurs when a person has power and usually lasts for a certain period of time. Hubris syndrome becomes a pattern of behavior of a person who sees (1) sees the world as a place for self-glorification through the use of power; (2) has a tendency to take action primarily to enhance personal image; (3) shows disproportionate concern for image and presentation; (4) exhibits messianic zeal and 
exaltation in speech; (5) conflates self with nation or organization; (6) uses the royal 'we' in conversation; (7) shows excessive self-confidence; (8) manifestly has contempt for others; (9) shows accountability only to a higher court (history or God); (10) displays unshakeable belief that they will be vindicated in that court; (11) loses contact with reality; (12) resorts to restlessness, recklessness, and impulsive actions; (13) allows moral rectitude to obviate consideration of practicality, cost or outcome; and (14) displays incompetence with disregard for nuts and bolts of policy making. (Owen and Jonathan, 2009)

The same thing was conveyed by Corsini in Jakovlyevic (2011) stating that Hubris syndrome is also expressed in the study of Political Psychiatry and is a symptom of power poisoning with dangerous impacts, both for the perpetrators and the surroundings. People who experience Hubris syndrome in political activities tend not to think about community welfare and do not care about the adverse effects caused by subjective political decisions. So if the person gets the top position, then he will become a tyranny with an intolerant and undemocratic personality; tending to have a cruel attitude. As a result, people who experience Hubris syndrome tend to live alone because they will be shunned by their environment. Thus, people who have Hubris syndrome will always feel lonely.

\section{Research Method}

This research is conducted by means of qualitative descriptive method proposed by Miles and Huberman (1994) as it is related to social phenomena reflected from the novel. Syndrome of Hubris is not only found in the novel but it is associated with any member of society and such a syndrome may come to anyone. In addition, phenomenological approach is also applied to conceive assumptions on personal experiences, feelings and reactions to certain situations; all of which centered around the syndrome of Hubris of the protagonist. (Husserl in Moran, 2013)

By this, it is clear that phenomenology is a direct study or investigation of certain phenomena depicted from a person or a group of people owing to certain events or conditions. The data collection procedures are also supported by in-depth interviews involving respondents, having proportional information about Hubris. On the whole the data collections procedures contain three stages: 1. data reduction in which coding and discarding irrelevant data are done; 2. Displaying all the data relevant to the objects of research; and 3. Drawing conclusions that all the data already taken are to be displayed and discussed. The data are taken from the novel while the data sources are sentences and phrases taken from the novel referring to the syndrome of Hubris. Other relevant data are also taken to support the whole research, such as those from books, journal articles and internet websites.

\section{Discussion}

The research is focused on a central figure of the novel named Ahab, standing as a captain on a whale hunting vessel, Pequod. The novel provides a visual reality about the adventures of brave sailors, whose lives are adjacent to death. All of this has a tense effect on the readers. The description gives the impression of authenticity because the story is written based on Herman Melville's experience.

The word 'Ahab' derives from the name of a king in Old Testament; he is the only ruler who dares to oppose God of Israel. A person who opposes God, whatever the reason is, is a rebel, someone who does not believe in the teachings of God and such is 
a manifestation of Satan because Satan never wants to submit to God. Captain Ahab is not a Satan; Melville simply illustrates that Ahab has demonic traits, having been obsessed in revenge on a whale, something irrational. (Egloff, et. al., 2017)

Everyone can become an Ahab, especially when the person has power and what Ahab experiences or suffers is termed Hubris syndrome, a pattern of behavior that is intolerant to everyone and feels that he can do anything according to his wishes and has a belief that whatever desired could be realized.

\section{Narcissistic Propensity}

Narcissistic Propensity is a part of Hubris syndrome and commonly called narcissistic personality disorder, a mental state that directs someone to be selfish, asking for attention and excessive admiration, and does not have a sense of empathy for the problems experienced by those around. Mentally, a person like this does not have strong principles because he can easily be provoked by the slightest criticism. Anger or high emotion is the color of everyday life. Someone who has a personality like this tends to have no friends because he has difficulty interacting with other people. Constraints always arise in all lines of life and life is always tinged with disappointment, sadness and depression, without a clear reason or causative factor. (Campbell, 2006). In short, one who feels superior without real evidence, dominating communication, underestimating others and acting with arrogance has shown features of narcissistic propensity and these features are shown by Captain Ahab.

If thou could'st, blacksmith, glad enough would I lay my head upon thy anvil, and feel thy heaviest hammer between my eyes. Answer! Can'st not smoothe this seam? (Melville, 1851: 113).

This is a picture of Captain Ahab acting in a very arrogant manner. He wants to show his subordinates that he is an unmatched superhuman. Here Captain Ahab wants to make a harpoon; he comes to the blacksmith and in a rude manner he gives the order that a harpoon must be finished immediately. He then states that he wants to put his head on the table and feel the heaviest hammer to be struck between his eyes. These words show how arrogant he is. As a leader, a captain, he must provide examples that can be set as examples. He does not hesitate to say indirectly that he is a great human being. Ahab does not realize that arrogance is a great sin and will never benefit either himself or those around him.

One who cannot get rid of arrogance and show-off will always suffer. Life will not be calm and one will always be shunned by society. Captain Ahab exalts his pride too high, and that self-exaltation becomes the source of his pride. He does not want to understand that there is heaven above the sky. Pride, hardness of heart and haughtiness are the main features of Captain Ahab, all of which brings Ahab to suffer even more.

The next narcissistic propensity shown by Captain Ahab is illustrated below.

"Ego non baptizo te in nomine patris, sed in nomine diaboli!"

deliriously howled Ahab, as the malignant iron scorchingly devoured

the baptismal blood (Melville, 1851:113).

"I baptize you, not in the name of the Father, but in the name of the Devil!", this is the essence of his words. By asking the blood of three crew members, Captain Ahab dips the harpoon's blade and says that he baptizes the harpoon in the name of Satan. This clearly illustrates that Captain Ahab suffers from mental illness. He opposes God, 
and considers that Satan is greater than God; that is why he calls the name of Satan to give a blessing for the use of the harpoon, which will personally be used to kill Moby Dick.

In this case, everyone, including the crew, is confused by the faith adopted by Captain Ahab. He seems to have allied himself with Satan and all his actions during his captaincy on Pequod ship show that he is anti-God. The use of blood and the mention of the name Satan show that he belongs to the group of Satanists. If Ahab is a theist, surely he will name God in all activities. For adherents of theist teachings, the mention of Satan's name is a big mistake and can result in evil. Ahab does not believe all these things. For him he is a great person achieving his greatness not because of help or support from any party, but because of his own efforts. And he suffers because of his own actions and he could avenge anyone who has made him miserable, including Moby Dick having removed one of his legs.

\section{Excessive Confidence}

One who has the nature of excessive self-confidence is basically making a way of referring to self-destruction and will be separated from environment because these traits have blinded the person concerned from logical thinking. People may have selfconfidence as a motivation to be more successful in life and as long as that selfconfidence is still within tolerance, everything can be running well.

Being a confident person is very good, because that is the key to success and the opportunity to be able to expand in matters of work or self-existence. However, having the nature of excessive self-confidence can harm oneself, and others. Neglecting advice, remarks and criticism is a feature of excessive self-confidence. Furthermore, someone who has excessive self-confidence always underestimates others because of the concept embedded in the mind that the ability possessed can solve all problems.

Excessive self-confidence will keep someone closed from input or suggestions from others; while as social beings people must support, remind and help each other. No one can live alone. A person who has excessive self-confidence is also prone to make mistakes and unfortunately, the person will not be able to do self-introspection; thus failure is a permanent shadow that always follows the journey of life.

Excessive self-confidence is the belief that an individual or organization possesses greater knowledge or skill than it actually has. Excessive self-confidence occurs in at least three distinct forms: misestimating, misplacing and misusing. (Russo and Paul: 2016) Then Moore and Healy in Russo and Paul (2016) states that excessive self-confidence is the belief that we have more knowledge or skill than we actually possess in a particular domain or task. It is one of the most pervasive and seductive illusions. Few escape it, even disciplined strategists. Excessive self-confidence always has high risks as stated by Kahneman in Prims and Moore (2017) that: There are profound day-to-day consequences of overconfidence. It has been called the most consequential of the biases to which human judgment is vulnerable.

The essence of excessive self-confidence can be described as follows. One who has excessive self-confidence tends to believe that the ideas possessed are the best. The person will not admit mistakes or weakness, and keep on criticizing others. And all this can be seen in Captain Ahab's personality.

Who told thee that?" cried Ahab; then pausing, "Aye, Starbuck; aye, my hearties all round; it was Moby Dick that dismasted me; Moby

Dick that brought me to this dead stump I stand on now. Aye, aye," he 
shouted with a terrific, loud, animal sob, like that of a heart-stricken moose; "Aye, aye! it was that accursed white whale that razeed me; made a poor pegging lubber of me forever and a day!" Then tossing both arms, with measureless imprecations he shouted out: "Aye, aye! and I'll chase him round Good Hope, and round the Horn, and round the Norway Maelstrom, and round perdition's flames before I give him up. And this is what ye have shipped for, men! to chase that white whale on both sides of land, and over all sides of earth, till he spouts black blood and rolls fin out. What say ye, men, will ye splice hands on it, now? I think ye do look brave" (Melville, 1851: 36).

Captain Ahab feels very confident that he would succeed in hunting down Moby Dick. Again he reminds everyone that he now has to use fake leg because of Moby Dick and he has to avenge the whale. His heart is burning and he could not wait longer to kill the whale. For Captain Ahab, Moby Dick is a monster to be eliminated or will give new terror to others. He with great confidence say that he would hunt the whale all over the world: Good Hope, Horn and along Norway Maelstrom. He gives motivation to the entire crew that they are brave sailors and they would succeed.

Captain Ahab does not realize that he is an ordinary human whose residence is not at sea; while the whale to be hunted is marine inhabitant and certainly more powerful than humans in movements in water. He does not think of the fate of the sailors forced to sail far without a definite destination and such a voyage would certainly make the sailors tired and run out of strength. Excessive self-confidence always gives negative impacts, both to the perpetrators and the people around them.

\section{Loneliness}

Everyone can feel alone; but feeling lonely is another thing and becomes a serious problem in life. When someone feels that he is living his own life alone, this means that he is not accompanied by someone else; but when a person feels lonely in life, he is practically isolated from social life which also means he has lost contact with the surrounding community. Losing contact with the community means that the person has no social relationship with anyone; while humans cannot live alone and mental suffering is the most obvious phenomenon for people like this. Feeling lonely in life is a very devastating feeling with the consequences of prolonged suffering.

Adolescents feel lonely when they perceive low level of social support, ignored, negatively evaluated, or rejected, by their family, peers, and other persons in the society, which has an adverse effect on their psychological development and their well-being. (Shaheen, et. al.: 2014)

People who feel lonely behave strangely because they feel that they have been banished from the society. Their personality cannot develop flexibly either. However, they are not discarded, but they throw themselves out of the society as a result of their own actions.

"Oh, Starbuck! it is a mild, mild wind, and a mild looking sky. On such a day - very much such a sweetness as this - I struck my first whale - a boy-harpooneer of eighteen! Forty - forty - forty years ago! ago! Forty years of continual whaling! Forty years of privation, peril, and storm-time! Forty years on the pitiless sea! For forty years has Ahab forsaken the peaceful land, for forty years to make war on the 
horrors of the deep! Aye and yes, Starbuck, out of those forty years I have not spent three ashore. When I think of this life I have led; the desolation of solitude it has been; the masoned, walled-town of a Captain's exclusiveness, which .... (Melville, 1851:132).

The description above shows that Captain Ahab lives an isolated life because there is no one close to him. He has been a whale hunter for forty years and for forty years, he has lost contact with people on land; in fact, he adds that during this period, he has at most three times put his feet on land. He feels that his life is filled with loneliness, far from the crowds and has been forgotten by relatives and family. This is so because he spends most of his life at sea.

Hubris Syndrome found in the novel is also illustrated in the community through the results of research by using 50 samples taken randomly. The sample is sourced from respondents taken from the population of employees working in both government and private agencies, and academicians in the city of Medan. Two research instruments are used: questionnaires and interviews. From the results, it is seen that there are three dominant traits indicated by someone with a leadership position: Narcissistic Propensity; Excessive Confidence and Loneliness. The results of the respondents' answers show that out of 50 samples, $92 \%$ or about 46 people agree that Narcissistic Propensity; Excessive Confidence and Loneliness are the attitudes shown by a leader. Through the interviews given, $92 \%$ of the total sample state that their leaders always show the attitude of Narcissistic Propensity; Excessive Confidence and Loneliness in their leadership. $8 \%$ of the total sample, around 3 people or $6 \%$ disagree with the three dominant attitudes of the leader mentioned above and there is 1 person or $2 \%$ who does not answer or does not know anything about this.

\begin{tabular}{|c|c|c|}
\hline Result & $\begin{array}{c}\text { Number of } \\
\text { Respondents }\end{array}$ & Percentage \\
\hline Agree & 46 & $92 \%$ \\
\hline Disagree & 3 & $6 \%$ \\
\hline No Answer & 1 & $1 \%$ \\
\hline
\end{tabular}

Table of Respondents' answer towards the dominant attitude of a leader realized in the novel Moby Dick

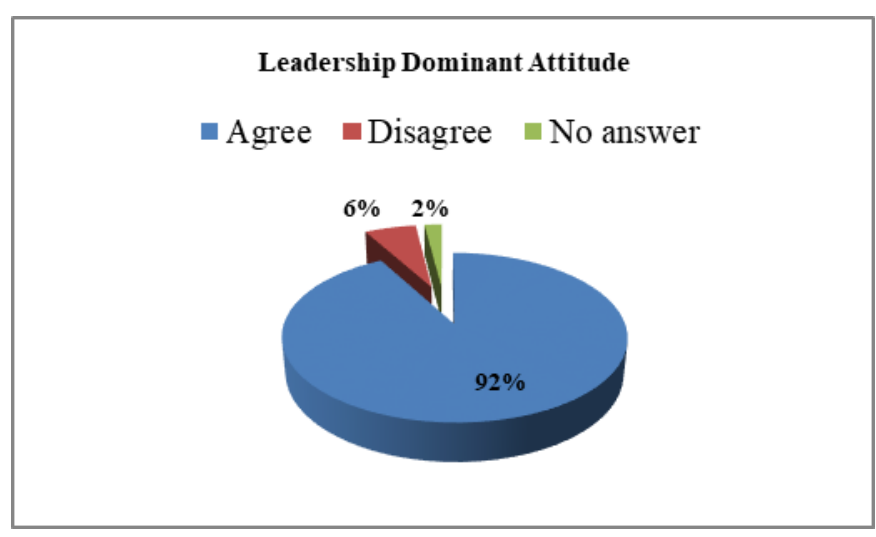

From the results of the research, it is illustrated that someone with leadership position experiences Hubris syndrome. Thus, it can be stated that Hubris syndrome in the novel is also a reality in the community. 


\section{Conclusion}

Moby Dick is the masterpiece of Herman Melville. The novel becomes the landmark in English literature, especially American literature. The research is focused on a captain named Ahab who in all his madness wants to avenge a whale he names Moby Dick. The real reason for Captain Ahab's revenge is that the whale has bitten off one of his legs and he feels that the whale is a symbol of evil and must be destroyed immediately. As a ship captain he has unlimited power and brings all the crew to hunt the whale. Ahab tries to uphold justice that is irrational and subjective.

Based on the research results and supported by the data validity through interviews and questionnaires, it is seen that Captain Ahab suffers from Hubris syndrome with three points of discussion close to his personality: Narcissistic Propensity, Excessive Confidence and Loneliness. Captain Ahab always feels that he is a superhuman and thirsts for praise. He always shows the crew that he is above them in all things and all his orders must be obeyed. He has excessive self-confidence. He easily says that he would travel all over the world to hunt the whale and he would succeed in killing the whale without thinking of the strength and preparation he has. As a result of Hubris syndrome he cannot interact with the people around him because they feel reluctant with him; thinking that being close to Captain Ahab means inviting trouble. Hubris syndrome always brings destruction; this happens to Captain Ahab. Finally, he has to give up because at the last hunt, the whale destroys everything on the ship and the rope used to hunt the fish ensnares Captain Ahab's neck and he dies.

Hubris Syndrome is a reality, a social phenomenon. Every leader or person a leadership position tends to have a Hubris syndrome. The development of Hubris syndrome is highly dependent on the individual's control. Hubris syndrome surely brings a destruction; more or less this syndrome is a tragic flaw.

\section{Reference}

Campbell, W. Keith. (2006). Narcissistic Personality Disorder. Chapter 42. ResearchGate. https://www.researchgate.net/publication/227240514_Narcissistic_Personality_ Disorder.

Diamandis, Eleftherios P and Nick Bouras. (2018). Hubris Science.7:133. ResearchGate. https://www.researchgate.net/publication/322874009_Hubris_and_Sciences.

Egloff, Goetz, Trin Fuchs, Dennis M. Jacobson. (2017). On Psychopathology and Existence: Ahab and Lear. International Journal of European Studies. Vol 1, No. 1. http://www.sciencepublishinggroup.com/j/ijes on.

Jakovlyevic, Miro. (2011). Hubris Syndrome and A New Perspective on Political Psychiatry: Need to Protect Prosocial Behavior: Public Benefit and Safety of Our Civilization. Psychitria Danubina. Vol. 23, No. 2. https://www.researchgate.net/publication/51231299_Hubris_syndrome_and_a_n ew_pers.

MacGill, Markus. (2017). What is Psychosis? Medical News Today. https://www.medicalnewstoday.com/articles/248159.php.

Manugeren, M and Hidayati. (2018). Universal Concept in Literary Work through J.M. Synge's Riders to the Sea. in The $1^{\text {st }}$ Annual International Conference on Language and Literature, KnE Social Sciences. DOI 10.18502/kss.v3i4.1958. 
Reality of Hubris Syndrome Through Herman Melville's Novel Moby Dick, Hidayati, Arifuddin, Aflina,

Melville, Herman. (1851). Moby Dick. PLANETEBOOK.COM. https://www.planetebook.com/free-ebooks/moby-dick.pdf.

Miles, Matthew B. and Huberman, A. Michael Huberman. (1994). Qualitative Data Analysis. California: Sage.

Moran, Dermot. (2013). Edmund Husserl and Phenomenology. ResearchGate. https://www.researchgate.net/publication/269696567_Edmund_Husserl_and_Ph enomenology.

Owen, David and Jonathan Davidson. (2009). Hubris Syndrome: An Acquired Personality Disorder? A Study of US President and UK Prime Ministers over the last 100 Years. Brain. Journal of Neorology. Vol. 132, Issue 5. https://academic.oup.com/brain/article/132/5/1396/354862.

Prims, Julian P. and Don A. Moore. (2017). Overconfidence over the Lifespan. Judgment and Decision Making. Vol. 12, No. 1. http://journal.sjdm.org/15/151024/jdm151024.pdf.

Russo, J. Edward and Paul Shoemaker. (2016). Overconfidence. ResearchGate. https://www.researchgate.net/publication/311907777_Overconfidence.

Shaheen, Hameeda, et. al. (2014). A Study of Loneliness in Relation to Well-Being among Adolescents. International Journal of Education and Psychological Research (IJEPR). Vol. 3, Issue 4. http://ijepr.org/doc/V3_Is4_Dec14/ij12.pdf. 